\title{
Fungsi Pengawasan DPRD Terhadap Pelaksanaan Perda APBD Kota Sorong No.32 Tahun 2014
}

\author{
A. Ardi \\ Fakultas Hukum, Universitas Muhammadiyah Sorong \\ Email : ardihadras12@gmail.com
}

\begin{abstract}
Abstrak
Untuk mengetahui apakah Dewan Perwakilan Rakyat Daerah Kota Sorong telah melaksanakan fungsi pengawasan terhadap pelaksanaan peraturan daerah tentang APBD Kota Sorong dengan baik atau belum. Untuk mengetahui hambatan/kendala dihadapi anggota Dewan Perwakilan Rakyat Daerah dalam melaksanakan fungsi, pengawasan tersebut. Untuk mengetahui cara mengatasi hambatan atau kendala yang timbul sebagai akibat dari pelaksannaan fungsi pengawasan. Untuk mengetahui mekanisme pengawasan terhadap pelaksanaan peraturan daerah tentang APBD oleh DPRD.
\end{abstract}

Kata kunci : Fungsi Pengawasan DPRD Terhadap Pelaksanaan Peraturan Daerah Tentang Anggaran Pendapatan dan Belanja Daerah Kota Sorong mutlak menuju pemerintahan yang bersih dari KKN.

\section{PENDAHULUAN}

Reformasi Undang-Undang Dasar Negara Republik Indonesia tahun 1945 telah dilaksanakan oleh Majelis Permusyawaratan Rakyat Republik Indonesia/MPR RI sebanyak 4 (empat) kali sejak 1999-2002 diharapkan membawa perubahan dan semangat baru dalam rangka penyelenggaraan ketatanegaraan dan pelaksanaan sistim pemerintahan yang lebih demokratis, transparansi, akuntabilitas, guna mewujudkan pembangunan nasional yang adil dan merata keseluruh daerah.

Otonomi daerah bukan merupakan kebijakan yang baru dalam sistim ketatanegaraan dan penyelenggaraan pemerintahan di Indonesia karena telah ditegaskan didalam pasal 18 ayat (1) dan ayat (2) UU Dasar Negara Republik Indonesia tahun 1945 perubahan sistim penyelenggaraan Pemerintahan Negara Republik Indonesia sejak UU nomor 5 tahun 1974 tentang pokok-pokok pemerintahan daerah, kemudian diubah dengan UU nomor 22 tahun 1999 tentang pemerintahan daerah kemudian UU nomor 25 tahun 1999 tentang perimbangan keuangan antara pusat dan daerah sampai pada UU nomor 32 tahun 2004 tentang pemerintahan daerah yakni dari sistim Sentralisasi ke-sistim Desentralisasi, telah membawa perubahan yang pundamental. Demikian pula kedudukan dan independensi DPRD memiliki keleluasaan dan kekuatan dalam menjalankan fungsi dan kewenangannya serta diharapkan menjadi lembaga perwakilan rakyat yang benar-benar mendengar, menerima dan mampu memperjuangkan aspirasi atau kehendak rakyat kepada 
pemerintah guna mensejahterakan rakyat dalam bingkai Negara Kesatuan Republik Indonesiadari Sabang sampai Merauke.

Dalam rangka penyelenggaraan pemerintahan yang lebih baik, maka partisipasi aktif masyarakat sangat dibutuhkan didalam perumusan dan pembentukan peraturan daerahmelalui wakil-wakilnya dilegislatif yang dipercaya untuk membawa aspirasi masyarakatsebagai dasar untuk perumusan, pembahasan penetapan peraturan daerah dan perundang-undangan sertakebijakan-kebijakanstrategis pembangunan daerah Dalam hal pembuatan peraturan daerah pentingnya partisipasi masyarakat menurut :

Bagir Manan,“Bahwa ajaran negara kesejahteraan (Versorgingsstaat atau welfare state), mengandung esensi bahwa negara atau pemerintah memikul beban dan tanggungjawab dankewajiban untuk mewujudkan dan menjamin kesejahteraan umum (public welfare atau social justice). ini dibebankan kepada badan kekuasaan negara yang diberikan amanat oleh konstitusi. Termasuk didalamnya adalah lembaga legislatif (DPR) yang dalam kedudukannya sebagai lembaga negara memiliki kewajiban untuk mewujudkan kemakmuran rakyat."

Untuk mensejahterakan segenap Rakyat Indonesia, sebagaimana dimaksud dalam UndangUndang DasarNegara Republik Indonesia tahun1945 pada alinea ke-empat yang berbunyi“Maka disusunlah pemerintahan Negara Republik Indonesia, untuk melindungi segenap bangsa Indonesia, dan seluruh tumpah darah Indonesia, memajukan kesejahteraan umum, mencerdaskan kehidupan bangsa dan ikut melaksanakan ketertiban dunia, yang berdasarkan perdamaian abadi dan keadilan sosial dan seterusnya, maka pemerintah bersama lembaga perwakilan rakyat baik ditingkat pusat maupun di daerah, diharapakan dapat melaksanakan pembangunannasional disegala bidang dengan modal kekayaan alam yang melimpah untuk mewujudkannegara hukum/negara kesejahteraan seluruh rakyat indonesia. Melalui otonomi daerah yang telah diatur dalam pasal 18 Undang-Undang Dasar Negara Republik Indonesia tahun 1945, kemudian lahirnya UU Nomor 22 tahun 1999 tentang otonomi daerahyang pada inti pelaksanaan-nya adalah adanya keleluasaan pemerintah daerah untuk menyelenggarakan pemerintahan sendiri atas dasar prakarsa dan peranserta masyarakat dalam memajukan daerahnya sesuai cita-cita bersama.

Berkaitan dengan otonomi daerah maka diharapkan DPRD dan pemerintah daerah menjalankan tugas dan fungsi dengan baik dan saling memberikan penguatan sehingga otonomi daerah dapat meniupkan angin segar bagi kemajuan daerah. Dasar pertimbangan undang-undang 
ini menyebutkan bahwa penyelenggaraan otonomi daerah diperlukanuntuk lebih menegaskan prinsip demokrasi, dan meningkatkan peran serta masyarakat.

Begitupulah bunyi pasal 1 butir h UU Nomor 32 tahun 2004 bahwa otonomi daerah akan mampu membawa perubahan positif yang signifikan dari sistim pemerintahan sentralistik ke sistim pemerintahan desentralisasi yang mengakomodir kewenangan daerah otonom untuk mengatur dan mengurus kepentingan masyarakat daerah menurut prakarsa sendiri berdasarkan aspirasi masyarakatdan sesuai peraturan perundang-undangan. Kemudian bunyi pasal 1 UU Nomor 22 tahun 1999 ini merupakan perubahan mendasar atas pasal 1 butir c UU Nomor 5 tahun 1974tentang pemerintahan daerah didalam UU ini otonomi daerah hanya ada kata mengatur, sedangkan bunyi pasal 1 UU Nomor 22 tahun 1999 terdapat kata mengatur dan mengurus.

Undang-Undang otonomi daerah menegaskan bahwa keberadaan pemerintah daerahbukan hanya mengatur tetapi juga mengurus kepentingan masyarakat daerah.Otonomi daerah harus dapat memberikan arah bagi keleluasaanpenyelenggaraan pemerintahan daerah, pembinaan kemasyarakatandan pembangunan secara menyeluruh, dengan menggali dan memanfaatkan potensi Sumber Daya Alam dan penerimaan pajak serta sumber pendapatan lainnya digunakan sebesar-besarnya untukkemakmuran rakyat di daerah. Dalam kaitannya dengan otonomi daerah yang bersumber dari pemerintah pusat dalam rangka percepatan pembangunan daerah menurut C.F. StrongbahwaAsas Desentralisasiadalahpelimpahankewenangan / urusan pemerintahan dari pemerintah pusat sebagai tingkat atasannya kepada daerah menjadi urusan rumah tangga daerah yang bersangkutan.

Azas desentralisasi ini merupakan sistim penyelenggaraan pemerintahan dititik beratkan kepada daerah kabupaten/kota sehingga daerah kabupaten/kota memiliki keleluasaan untuk mengelola rumah tangga daerahnya dengan prinsip otonomi daerah. Hal ini sesuai Ketetapan MPR Nomor XV/ MPR/1998 tentang penyelenggaraan otonomi daerah sebagai berikut: "Penyelenggaraan Otonomi Daerah dilaksanakan dengan memberikan kewenangan yang luas, nyata dan bertanggungjawabkepada daerah secara proporsional yang diwujudkan dengan pengaturan, pembagian, dan pemanfaatan sumber daya nasional yang berkeadilan, serta perimbangan keuangan Pusat dan Daerah. Penyelenggaraan otonomi daerah juga dilaksanakan dengan prinsip-prinsip Negara Kesatuan Republik Indonesia, demokrasi, peran serta masyarakat, pemerataan pembangunan dan keadilan, serta memperhatikan potensi dan keanekaragaman daerah 
yang didukung oleh semangat otonomi, pelaksanaan yang berkualitas serta sarana dan prasarana yang memadai".

Berkaitan dengan otonomi daerah urusan pemerintah pusat diatur dalam pasal 10 ayat (3) UU Nomor 32 tahun 2004 menyatakan bahwa urusan pemerintah pusat meliputi:(1) Politik Luar Negeri; (2) Keamanan, (3). Pertahanan; (4)Yustisia/hukum; (5) Moneter dan fiskal nasional; dan (6) Urusan Agama. Kewenangan diluar semua itu adalah kewenangan/urusan pemerintah daerah untuk menyelenggarakannya, terdapat pembagian urusan yang terdiri atas urusan wajib dan urusan pilihan. Sesuai pasal 14 UU No. 32 tahun 2004, urusan rumah tangga daerah wajib menjadi kewenangan pemerintah daerah Kabupaten/Kota meliputi; (1) Perencanaan dan pengendalian pembangunan daerah; (2) Perencanaan, pemanfaatan dan pengawasan tata ruang; (3) Penyelenggaraan ketertiban umum dan ketenteraman masyarakat; (4) Penyediaan sarana dan prasarana umum; (5) Bidang kesehatan; (6) Bidang Pendidikan; (7) Penangggulangan masalah sosial; (8) Bidang ketenagakerjaan; (9) Pengembangan Koperasi dan UKM; (10) Lingkungan Hidup;(11)Pelayanan Pertanahan;(12) Kependudukan dan Pencatatan Sipil; (13) Pelayanan Administrasi Umum Pemerintahan; (14) Administrasi Penanaman Modal; (15) Pelayanan dasar lainnya; dan (16)Urusan wajib lainnya yang selanjutnya diatur oleh undang-undang.

Sedangkan urusan pilihan adalah urusan pemerintahan daerah yang secara nyata dapat meningkatkan kesejahteraan masyarakat sesuai keunggulan daerah. Menurut Wolhoff,dalam Negara Kesatuanseperti Indonesia kekuasaan tidak terbagi, pada dasarnya seluruh kekuasaan dikendalikan pemerintah pusat,sehingga peraturan sentrallah yang menentukan bentuk dan susunan daerah otonom. Selanjutnya wolhoff juga mendefenisikan Asas desentralisasi sebagaibentuk penyerahan kewenangan kepada daerah untuk mengatur dan mengurus rumah tangganya sendiri menurut inisiatif /prakarsa sendiri (otonom).

Penyerahan kewenangan dimaksud merupakan wujudkedaulatan rakyatsecara demokrasi dimana hak rakyat daerah diberikan ruang gerak lebih luas untuk berpartisipasi dalam merencanakan, merumuskan, peraturan-peraturan dan menentukan urusan rumah tangga pemerintahan daerah sendiri, serta mengevalusi kebijakan-kebijakan pemerintah secara langsung maupun melalui para wakilnya di lembaga legislatif /DPRD.

Hal tersebut diatas diperkuat oleh Wahyu Kumorotomo(1996:112), berpendapat bahwa "diera otonomi daerah seperti saat sekarang ini yang dibutuhkan adalah partisipasi masyarakat secara aktif ikut menentukan kebijakan menyangkut hajat hidup masyarakat itu sendiri”. 
Dalam hubungan dengan diatas,menurut Huntington dan Nelson, Bahwa "Partisipasi masyarakat dalam pembuatan hukum diartikan sebagai kegiatan politik warga negara sipil (Private Citizen) yang bertujuan untuk dapat mempengaruhi pengambilan keputusan bagi pemerintah".

Dalam rangka terbukanya ruang sosial politik yang diwakili oleh lembaga perwakilanrakyat daerah dengan pemerintah daerah sesuai UU nomor 32 tahun2004 tentang pemerintahan daerah maka ditegaskan bahwa pemerintah daerah adalahkepala daerah bersama Dewan Perwakilan Rakyat Daerah/DPRD membina kerjsama yang harmonis dalam menjalankan tugas dan fungsi masing-masing. Berkaitan dengan hubungan partai politik dengan anggota legislatif, menurut R.H.Saltouw yang dikutip oleh Moh.Kusnardi dkk, Dalam Ilmu Negara, hal.267,"Bahwa anggota legislatif dari partai politik dan utusan daerah yang diwakilinya untuk mewakili masyarakat dalam pembuatan peraturan perundang-undangan, pelaksanaan peraturan perundang-undangan, peraturan daerah, pengawasan perda, pengawasan anggaran, dan pengawasan kebijakan lainnya".Lebih lanjut Moh.Kusnardi katakana, bahwa partai politik sebagai suatu susunan golongan pelaku politik aktif terorganisir dalam persamaan ideologis/ kehendak dan bertindak sebagai suatu kesatuan politik dengan penggunaan kekuasaan memberikan suara bertujuan merebut kekuasaan, mengawasi pemerintahan, dan memperjuangkan aspirasi serta kehendak rakyat tanpa kecuali.

Berdasarkan pendapat diatas, disimpulkan bahwa perlunya penguatan fungsi dan wewenang para legislatif yang lahir dari partai politik untuk mewakili rakyat yang memilihnya sehingga kebijakan-kebijakan penguasa untuk kemaslahatan rakyat banyak dapat diakomodir. Diera reformasi saat ini Dewan Perwakilan Rakyat Daerah Kabupaten/Kotasebagai lembaga legislatif daerah yang dipilih oleh masyarakat daerah diharapkan memiliki kemampuan dengan modal pendidikan, pengalaman, pemahaman sistim politik dan niat yang baik untuk menjalankan fungsi-fungsi dan peranannya dengan bermitra dengan kepala daerah dan pendekatan dengan masyarakatuntuk menjaring asmara, menerima serta memperjuangkan / menyalurkan kehendak masyarakat kepada pemerintah, kepada pihak lain yang ada hubungannya, dan memfasilitasi bagi pihak-pihak yang bermasalah. Peluang untuk itu dibukakan pintu lebar oleh UU Nomor 22/1999, dalam pasal 22 butir c,d, dan e secara tegas dinyatakan bahwa DPRD mempunyai kewajiban untuk membina kehidupan demokrasi.

DPRD mempunyai fungsi pengawasan/mengontrol pelaksanaan peraturan daerah dan peraturan perundang-undangan lain serta kebijakan yang diselenggarakan oleh pemerintah daerah 
agar dapat berjalan sesuai ketentuan dan harapan masyarakat. DPRD juga berhakmemberikan pendapat atau pertimbangan dalam pembahasan, perumusan dan penetapan peraturan daerah sertakebijakan-kebijakan pemerintah dengan skalah prioritas pembangunan untuk meningkatkan kesejahteraan rakyat daerah berdasarkan demokrasi ekonomi, dengan memperhatikan partisipasi dan aspirasi masyarakat.

Disamping fungsi legislasi, fungsi anggaran dan fungsi pengawasan, DPRD juga mempunyai peranan atau tugas lainnya yang bersifatdarurat yang tidak terencana tetapi sama pentingnya dengan tugas lainnyaseperti menerima dan menyalurkan aspirasi masyarakat (Asmara). DPRD dalam menjalankan fungsi dan wewenangnya sering mendapatkan tanggapan beragam dimasyarakat, apakah benar atau tidak, tentu diakui bahwa berbagai keberhasilan yang telah diukir oleh legislatif kita, tetapi dibalik keberhasilan itu, juga masih ada kelemahankelemahanbaik disengaja atau tidakdisengaja, sebagai manusia biasa tentunya terdapat kekurangan dan kehilapanyang sudah barang tentu menjadi salah satufaktor yang menyebabkanhal tersebut terjadi.;(1) Apakah DPRD telah melaksanakan fungsi pengawasan terhadap Pelaksanaan perda.tentang APBD Kota Sorong Nomor 32 tahun 2014 dengan baik ?; (2) Kendala atau hambatan apasaja yang dihadapiDPRD dalam melaksanakan fungsi pengawasan tersebut?

\section{PEMBAHASAN}

\section{Anggaran Pendapatan dan Belanja Daerah}

Anggaran Pendapatan dan Belanja Daerah selanjutnya disingkat APBD, sebagaimana yang termaktub dalam pasal 1 ayat (23) tentang tatatertib DPRD Kota Sorong pada Bab I ketentuan umum bahwa APBD adalah rencana keuangan tahunan Kota Sorong yang ditetapkan dengan peraturan daerah.

Penguatan kapasitas anggota DPRD dalam manunaikan fungsi dan tugasnya termasuk fungsi penganggaran hendaknya perlu memperhatiakan semua aspek yang termasuk didalamnya. Fungsi pengawasan terhadap pelaksanaan anggaran perlu secara tegas dan ketat adanya akuntabilitas transparansi anggaran, anggota DPRD hendaknya perlu pengenalan dan penyesuaian terhadap kompleksitas kebijakan penyusunan anggaran daerah.Terhadap peningkatan PAD diarahkan kepada sumber daya anggaran daerah dengan melalui suntikan investasi di daerah. DPRD sebagai manipestasi dari rakyat yang mendukungnya di daerah dan sebagai mitra kerja pemerintah hendaknya melakukan terobosan dalam pengelolaan APBD. Kebijakan baru dalam 
proses penganggarandi DPRD hendaknya berdasarkan dua syarat umum, Pertama bahwa dalam penyusunan anggaran perlu memperhitungkan kepentingan partai politik dan kepentingan kelompok masyarakat pendukung melalui proses pemilu legislasi, hal ini dimaksudkan bahwa keterlibatan masyarakat dalam proses pengelolaan anggaran daerah terlihat dengan wakilnya di parlemen.

Kedua, DPRD perlu memahami/menguasai rumus mengenai kebijakan pemerintah dalam kaitan dengan pembangunan dan penggunaan anggaran di daerah. tanpa kapasitas itu sulit bagi Dewan untuk menilai dan mengevaluasi dan memberikan persetujuan terhadap usulan anggaran yang diajukan oleh pemerintah daerah, misalnya :

\section{Perda sebagai dasar fungsi penganggaran dan pengawasan bagi DPRD,}

Peraturan daerahjuga merupakan produk hukum atau kebijakan di daerah, melalui perda pemerintah menetapkan program pembangunan dalam rangka peningkatan kemakmuran dan kesejahteraan masyarakat daerah. Kemudian program pembangunan merupakan acuan bagi pembuatan legislasi(pembentukan peratuan daerah). Selain merupakan produk hukum, Perda juga merupakan bentuk kontrak DPRD dengan pemerintah dalam rangka meningkatkan kesejahteraanrakyat daerah. Dalam menetapkan program pembangunan daerah, perda juga merupakan pedoman dan acuan mutlak sehingga pembangunan berjalan sesuai yang ditetapkan dalam perda tersebut. Dari ketiga fungsi DPRD, fungsi legislasi merupakan fungsi utamakarena fungsi legislasi berkaitan erat dengan fungsi lainnya dan kedua fungsi yang lain bersumber pada fungsi legislasi. Pelaksanaan fungsi anggaran adalah pelaksanaan fungsi legislasi demikan pula pelaksanaan fungsi pengawasan merupakan penerapan fungsi pengawasan pelaksanaan perda yang dalam bentuk APBD yang diawali dengan Rancangan peraturan Daerah tentang APBD (RUU APBD). Perda disusun berkaitan langsung dengan fungsi penganggaran, karena masing-masing mata anggaran harus memperhitungkan kepentingan yang telah diatur oleh perda denga skala prioritas program pembangunan yang disepakati bersama pemerintah daerah. Pengelolaan keuangan daerah adalah bagian penting dari pelaksanaan APBD yang ditetapkan dengan perda Kabupataen/Kota sebagaimana diatur dalam PP Nomor 105/2000 tentang pengelolaan dan pertanggungjawaban Keuangan Negara dimana didalamnya disebutkan tentang ketentuan pokok pengelolaan Keuangan Daerah yang selanjutnya diatur dengan peraturan daerah Pasal 14 (2) Peraturan Pemerintah nomor 105/2000 berbunyi bahwaPeraturan daerah mengatur tentang garis besar prosedur penyususnan APBD, kewenangan kepala daerah dan DPRD, prinsip-prinsip 
pengelolaan kas daerah, Pengelolaan keuangan daerah, Tata cara pengadaan barang dan jasa, prosedur pinjaman daerah, prosedur pertanggungjawaban dan hal-hal lain yang relevan dengan pengelolaan keuangan daerah. Proses penyusunanAPBD dengan pendekatan kinerja memuat dua hal pokok; (a) Standar Pelayanan yang diharapkan dan perkiraan biaya satuan setiap komponen kegiatan yang bersangkutan; (b) Bagian pendapatan APBD membiayai belanja administrasi umum, belanja operasi dan pemeliharaan serta belanja modal/pembangunan.

Pendekatan dimaksudkan diatas pada dasarnya penyesuaian program pembangunan yang telah disepakati antara DPRD dengan pemerintah yang dituangkan dalam bentuk peraturan daerah. Agar pengelolaan keuangan daerah tertuang dalam APBD benar-benar sesuai kebutuhan daerah DPRD wajib melaksanakan fungsi pengawasan penggunaan anggaran sampai pada tahap evaluasi, selanjutnya agar APBD dapat tersusun dan terlaksana tepat sasaran serta tepat waktu, DPRD dapat mengarahkan penyusunan APBD berpedoman pada peraturan perundang-undangan yang berlaku dengan materi sebagai berikut ; (a) APBD disusun dengan pendekatan kinerja; (b) Dalam menyususn APBD, penganggaran pengeluaran harus didukung kepastian adanya penerimaan dalam jumlah yang cukup; (c) Jumlah pendapatan yang dianggarkan dalam APBD merupakan perkiraan terukur dan dapat dicapai; (d) Jumlah anggaran belanja yang disiapkan dalam APBD merupakan batas tertinggi untuk setiap jenis belanja; dan (e) Perkiraan sisa lebih perhitungan APBD tahun sebelumnya dicapai sebagai saldo awal pada APBD tahun berikutnya. Sedangkan realisasi sisa lebih perhitungan APBD tahun lalu dicatat sebagai saldo awal pada perubahan APBD.

Fungsi Anggaran Anggaran Daerahadalah suatu dokumen yang memuat perkiraan penerimaan dan pengeluaran serta rincian kegiatan-kegiatan penyelenggaraan pemerintahan daerah yang berasal dari pemerintah dalam jangka waktu satutahun anggaran. Jumlah penerimaan dan pengeluaran daerah direncanakana dengan cara berimbang untuk tahun anggaran daerah yang bersangkutan.

Untuk mengetahui sejauh mana kemampuan pemerintah mengelola anggaran sehingga tidak terjadi defisit anggaran maka peranan DPRD sangat menentukan agar tidak terjadi hal yang tidak diinginkan. Secara umum yang dimaksud dengan fungsi anggaran (Badget) DPRDadalah fungsi perencanaan, penyusunan, dan perumusan anggaran (keuangan) dalam rangka pembiayaan pembangunan serta pembiayaan semua kebijakan pemerintah dalam kurun waktu satu periode tertentu melalui APBD bersama dengan kepala daerah. 
Defenisi anggaran menurut ahli: Menurut Ahmad Helmy Fuady, (Dalam memahami anggaran publik,:2002 hal.10) bahwa anggaran adalah penyertaan tentang perkiraan penerimaan dan pengeluaran yang diharapkan dimasa yang akandatang dan realisasinya dimasa yang lalu. Anggaran berdampak bagi segenap aspek kehidupan masyarakat yang sangat berkepentingan dari proses pelaksanaan anggraran. Oleh sebab itu pengawasan anggaran Keuangan Daerah sangat penting bagi DPRD.

Makna anggaran dapat dilihat dari tiga pendekatan. Pertama secara Etimologis anggaran berasal dari bahasa Belanda, "Bergrooting" yang berarti mengirakan kemudian Bahasa Inggris "Budget" Bahasa Perancis "Boungette" yang berarti Tas pinggang yang terbuat dari kulit binatang dan digunakan untuk menyimpan surat-surat anggaran oleh Menteri Keuangan.

Dalam Bahasa Indonesia Anggaran berasal dari kata “Anggar” yang berarti "kira-kira atau perkiraan". Kedua dalam arti dinamis, anggaran adalah sebagai berikut : (1) Rencana keuangan yang menterjemahkan sumber-sumber yang tersedia untuk memenuhi aspirasi atau kehendak masyarakat guna pembiayaan pembangunan menuju penciptaan kehidupan masyarakat yang lebih baik; (2) Rencana keuangan pemerintah daerah untuk membiayai program pembangunan dan mendorong masyarakat untuk memenuhi kewajibannya agar kehidupan masyarakat lebih baik;(3) Proses penentuan alokasi sumber-sumber ekonomi untuk setiap program dan aktifitas dalam bentuk satuan nilai uang. Sistem penyususnan dan pengelolaan anggaran daerah yang berorientasi pada pencapaian hasil kerja atau disebut Anggaran kinerja. Kinerja harus mencerminkan efektifitas dan efesiensi pelayanan publik (Mardiasmo,2002: 105).

Selanjutnya Fungsi kedua DPRD adalah fungsi anggaran (Budget) adalah fungsi DPRD bersama kepala daerah dalam merencanakan penyusunan anggaran (keuangan) daerah melalui anggaran pendapatan dan belanja daerah/APBD tiap periode anggaran yang daijukan dalam bentuk Raperda selanjutnya dibahas dan mendapat persetujan bersama; (4) Prinsip-prinsip Anggaran; Menurut Word Bank (1998), prinsip-prinsip pokok dalam anggaran dan manajemen keuangan daerah adalah sebagai berikut; (a) Komprehensip dan disiplin; (b) Pleksibilitas; (c) Terprediksi; (d) Kejujuran; (e) Informasi; dan (f) Tranparansi dan akuntabillitas

Kemudian Fungsi anggaran menurut UU Nomor 22/2003 pasal 77 huruf b penjelasan tentang susunan dan kedudukan MPR, DPR, DPD dan DPRD bahwa yang dimaksud dengan fungsi anggaran DPRD adalah"fungsi DPRD Kabupaten/Kota bersama pemerintah daerah untuk 
menyusun dan menetapkan APBD,termasuk di dalamnya untuk pelaksanaan fungsi, tugas, dan wewenang DPRD Kabupaten /Kota.

Dalam pengertian lain fungsi anggaran adalah fungsi DPR untuk menyusun dan menetapkan anggaran pendapatan dan belanja daerah bersama kepala daerah dan apabila RAPBD tersebut telah disetujui dan disahkan bersama,maka menjadi Peraturan Daerah (perda). Fungsi anggaran merupakan fungsi kedua dari fungsi DPR dan DPRD karena anggaran/keuangan merupakan posisi sentral dalam rangka pembiayaan penyelenggaraan pembangunan disemua sektor baik skala nasional maupun daerah.

Fungsi penganggaran oleh Dewan merupakan salah satu fungsi penyusunan dan penetapan APBD, dalam menjalankan fungsi dan kewajibannya DPRD terikat secara aktif, proaktif, dan bukan reaktif dan sebagai leditimator usulan APBD ajuan pemerintah daerah. fungsi anggaran perlu perhatian penuh, mengingat makna pentingnya anggaran sebagai berikut ; (1) APBD sebagai fungsi kebijakan fiscal ( fungsi alokasi, fungsi distribusi dan fungsi stabilisasi; (2) APBD sebagai fungsi insvestasi daerah; (3) APBD sebagai fungsi manajemen pemerinthana daerah, perencanaan, fungsi otorisasi, fungsi pengawasan ).

Pengawasan Keuangan Negara : Pengeluaran pemerintah dari tahun ke tahun semakin meningkat sehingga penyelenggaraan program pemerintah dilaksanakan cenderung kurang hemat dan kurang efesien, maka pengawasan hendaknya ditingkatkan. Pengawasan bukan hanya mencakup penggunaan anggaran dan ketaatan terhadap peraturan yang berlaku, melainkan juga pengawasan terhadap kehematan dayaguna dan hasil guna program pembangunan Pemerintah agar berjalan sesuai ketentuan. Menurut Poerwadarminta dalam Kamus Bahasa Indonesia pengawasanadalah bentuk pemeriksaan atau pengontrolan dari pihak yang lebih tinggi kedudukannya kepada pihak yang lebih rendah dibawahnya. Jadi dapat disimpulkan bahwa pengawasan adalah suatu upaya agar apa yang telah direncanakan sebelumnya dapat diwujudkan dalam suatu waktu yang telah ditentukan serta dapat mengetahui kelemahan-kelemahan atau kesulitan dalam pelaksanaan sehingga perlu dilakukan suatu tindakan perbaikan demi tercapainya tujuan semula. Salah satu teknik pengawasan yang sering dilakukan adalah pemeriksaan, yaitu untuk menilai apakah hasil pelaksanaan telah sesuai dengan yang seharusnya, dan sekaligus dapat mengidentifikasi adanya penyimpangan atau hambatan-hambatan sekaligus mencari jalan penyelesaian dari hambatan tersebut. Tujuan pengawasan bukan untuk mencari-cari siapa yang salah dan siapa yang benar akan tetapi mengamati apa yang sedang terjadi dan membandingkan 
apa yang seharusnya terjadi sehingga secepatnya mengambil tindakan perbaikan. Sebenarnya tujuan utama pengawasan adalah untuk memahami apa yang salah demi perbaikan dimasa yang akan datang, dan mengarahkan seluruh kegiatan-kegiatan dalam rangka pelaksanaan suatu rencana agar mendapatkan hasil yang maksimal.

Dalam kondisi sehari hari sering terjadi penyimpangan atau penyelewengan oleh oknum tertentu hal terjadi karena disengaja untuk mendapatkan manfaat atau keuntungan pribadi atau golongan tertentu, ada pula terjadi penyimpangan karena keadaan memaksa dihadapi (force majeure)atau kondisi dilapangan tidak sesuai rencana sebelumnya. Agar pelaksanaan pengawasan dapat dijadikan sebagai suatu alat(instrumen) yang efektif, maka harus memperhatikan kriteria sebagai berikut; (1) Apa yang akan diawasi ( objek yang perlu diawasi ); (2) Mengapa perlu pengawasan; (3) Dimana dan bagaimana dilakukan pengawasan, dan siapa yang melaksanakan pengawasan itu; (4) Pengawasan yang dilaksanakan hendaknya bersifat rasional, fleksibel, terus menerus dan fragmatis.

Apabila diaplikasikan dengan pengawasan keuangan negara, maka dapat simpulkan sebagai berikut ; (1) Objek dari penggawasan keuangan negara bukan hanya menitikberatkan pada sektor anggaran belanja saja, tetapi juga dari segi anggaran pendapatan Negara(APN), (pajak dan penerimaan non pajak); (2) Pengawasan keuangan negara diartikan sebagai usaha yang bersifat terus-menerus untuk mengetahui apakah aktifitas-akifitas yang menyebabkan pengeluaran Negara idak menyimpang dari ketentuan yang telah digariskan; (3) Maksud dilaksanakan pengawasan keuangan negara agar pengeluaran-pengeluaran negara (Pengeluaran Pemerintah Pusat) dan penerimaan Negara benar-benar berjalan semestinya.

Dari segi sifatnya pengawasan dibedakan antara pengawasan preventif dan pengawasan refresif.Pengawasan preventif adalah pengawasan yang berorientasi pada aspek pencegahan jangan terjadi kesalahan atau penyimpangan dikemudian hari, sedangkan pengawasan bersifat refresif adalah upaya memperbaiki kesalahan atau penyimpangan yang telah terjadi sehingga tidak terulang kembali dikemukdian hari.

Dalam konteks seperti inilah DPRD harus mampu memperbaiki prosedur dan system pengawasan yang lebih ketat, perlunya duduk bersama dengan lembaga-lembaga pemerintah untuk menyepakati ruang lingkup tugas fungsi dan kewenangan masing-masing sehingga penyimpangan atau kesalahan dapat dihindari. 
Pengawasan diera otonomi daerah menjadi sangat penting karena dalam penyelenggaraan sistim pemerintah daerah telah diberi kekuasaan seluas-luasnya oleh pemerintah pusat untuk mengatur urusan kepentingan daerahnya, termasuk beberapa pelimpahan kewenangan kepada pemerintah daerah sekaligus menjadi tanggungjawab pemerintah daerah.

Hal dimaksud erat kaitannya dengan penggunaan anggaran dalam rangka pengembangan proses politik demokrasi dan sistem ketatanegaraandiberbagai negara di dunia karena dengan pengawasan diharapkan dapat menjamin terwujud dan efektifnya akuntabilitas publik diberbagai lembaga pemerintahan bahkan disektor swasta sekalipun.Pengawasan dilaksanakan adalah pemeriksaan, yakni kegiatan menilai apakah hasil pelaksanaan sebenarnya telah sesuai dengan seharusnya sekaligus mengidentifikasi adanya penyimpangan atau hambatan.

Maka tujuan pengawasan adalah mengamati apa yang sebenarnya terjadi, dan melaporkan kepada pimpinan apabila terdapat penyimpangan atau hambatan dan secepatnya mengambil tindakan perbaikan yang dianggap mendesak.

Tipe-tipe Pengawasan dalam ilmu manajemen dikenal ada tiga macam antara lain; (a) Tipe pengawasan pendahuluan (feedforward control) Tipe pengawasan seperti ini dimaksudkan untuk mengantisipasi timbulnya masalah-masalah atau penyimpangan dari standar yang ada atau dari tujuan memungkinkan adanya koreksi sebelum suatu tahap tertentu kegiatan atau renana diselesaikan; (b) Tipe pengawasan Current Tipe pengawasan semacam ini merupakan proses dimana aspek tertentu dari suatu prosedur harus disetujui, atau syarat-syarat tertentu dipenuhi terlebih dahulu sebelum kegiatan-kegiatan dilanjutkan atau pada aspek sarana, peralatan guna menjamin ketepatan terlaksananya biaya tenaga kerja, biaya penjualan, laba, pendapatn penjualan dan sebgainya kegiatan; (c) Tipe pengawasan umpan balik (feedback control) Tipe pengawasan ini menakar hasil-hasil dari suatu kegiatan yang diselesaikan. Pengawasan semacam ini bersifat mengukur yang dilakukan setelah kegiatan selesai.

Tahap-tahap proses pengawasan dibedakan menjadi 5 (lima tahap) antara lain : Standar mengandung sebagai suatu satuan pengukuran yang digunaakan sebagai patokan untuk penialian hasil-hasil ; (1) Standar-standar fisik, meliputi kualitas barang atau jasa, jumlah langganan atau kualitas suatu produk; (2) Standar-standar moneter, yang ditujukan dalan rupiah dan mencakup biaya tenaga kerja, biaya tenaga penjualan, labah, pendapatan penjualan dan sebagainya; (3) Standar-standar waktu, meliputi kecepatan suatu produksi atau batas waktu suatu pekerjaan yang harus diselesaikan. 
Pentingnya pengawasan adalah hal mutlak bagi setiap organisasi. Ada beberapa faktor yang menyebabkan pengawasan semakin penting antara lain sebagai berikut: (a) Perubahan lingkungan organisasi Berbagai perubahan dalam lingkungan organisasi secara terus-menerus tak dapat dihindari, dengan pengawasan yang efektif, organisasi mampu menghadapi tantangan atau memanfaatkan kesempatan yang diciptakan perubahan-perubahan yang terjadi; (b) Peningkatan kompleksitas organisasi; Semakin besar suatu organisasi semakin kompleks pula kegiatan atau aktifitas organisasi tersebut, sehingga memerlukan pengawasan yang lebih formal dan ketat; (c) Kesalahan-kesalahan; Apabila bawahan tidak pernah membuat suatu kesalahan atau kekeliruan, manajer dapat melakukan pengawasan, tetapi tidak dapat dipungkiri bahwa banyak juga suatu organisasi melakukan suatu penyimpangan atau kesalahan, maka sistem pengawasan memungkinkan manajer dapat mendeteksi kesalahan atau penyimpangan sebelum menjadi parah.

Maksud dan Tujuan Pengawasan ; (1) Maksud pengawasan menurut Situmorang dan Juhir (1994 :22) adalah untuk : (a) Mengetahui jalannya pekerjaan atau kegiatan apakah lancar sesuai atau tidak; (b) Memperbaiki kesalahan-kesalahan yang dilakukan oleh pegawai/karyawan dan mengadakan pencegahan agar tidak terulang kembali; (c) Mengetahui apakah penggunaan budget yang telah ditetapkan terarah dan sesuai perencanaan sebelumnya; (d) Mengetahui hasil pekerjaan dibandingkan dengan yang ditetapkan dalam perencanaan standar; dan (e) Untuk membina kepercayaan masyarakat terhadap kepemimpinan organisasi.; (2) MenurutRachman (1994 : 22 ), yaitu; (a) Untuk mengetahui apakah segala sesuatu berjalan sesuai dengan rencana yang telah ditetapkan sebelumnya; (b) Untuk mengetahui apakah segala sesuatu berjalan sesuai dengan instruksi serta prinsip-prinsip yang telah ditetapkan; (c) Untuk mengetahui apakah kelemahankelemahan atau kesulitan-kesulitan dan kegagalan-kegagalannya, sehingga dapat diadakan perubahan untuk memperbaiki serta mencegah pengulangan perbuatan yang salah; (d) Untuk mengetahui apakah sesuatu berjalan secara efesien dan apakah dapat diadakan perbaikanperbaikan lebih lanjut sehingga mendapat efesiensi yang lebih besar.

Tujuan pengawasan menurut : (A)Maman Ukas ( 2004 : 337 ) adalah sebagai berikut : (1) Mensuplai pegawai-pegawai manajemen dengan informasi-informasi yang tepat, telitih dan lengkap tentang apa yang akan dilaksanakan; (2) Memberi kesempatan kepada pegawai dalam meramalkan secara telitih rintangan-rintangan yang akan mengganggu produktifitas dan mengambil langkah-langkah secara tepat untuk menghapus atau mengurangi gangguan-gangguan 
yang terjadi; (3) Setelah kedua hal tersebut telah dilaksanakan, kemudian para pegawai dapat mempermuda menentukan langkah terakhir dalam mencapai produktifitas kerja yang maksimal serta pencapaian yang memuaskan dari hasil-hasil yang diharapkan.; (B) Menurut Situmorang dan Juhir (1994:26)"bahwa tujuan diadakan pengawasan adalah; (1) Agar tercipta aparat yang bersih dan beribawa yang didukung oleh sistem manajemen pemerintahan yang berdaya dan berhasil guna serta ditunjang oleh partisipasi masyarakat yang konstruktif dalam wujud pengawasan masyarakat ( Sosial control ); (2) Agar terselenggara tertib adminnistrasi dilingkungan aparat pemerintah dan disiplin kinerja yang baik; (3) Adanya keleluasaan dalam melaksanakan kegiatan, timbulnya budaya malu-malu dalam diri pribadi aparat, serta adanya rasa bersalah dan berdosa untuk berbuat yang tercela terhadap masyarakat dan ajaran agama.

Lebih lanjut Situmorang mengemukakan bahwa tujuan secara langsung pengawasan adalah: (1) Menjamin ketepatan pelaksanaan kegiatan sesuai rencana, kebijakan dan perintah;

2. Menertibkan koordinasi setiap kegiatan atau pekerjaan'

3. Mencegah pemborosan dan penyelewengan;

4. Menjamin terwujudnya kepuasan masyarakat atas baarang atau jasa yang aihasilkan;dan

5. Menumbuhkan dan membina kepercayaan masyarakat terhadap kepemimpinan dalam organisasi”.

\section{SIMPULAN}

Berdasarkan hasil penelitian yang telah dilakukan oleh penulis baik penelitian kepustakaan maupun penelitian empiris/sosiologis dan pengamatan yang mendalam terhadap objek penelitian, ditemukan fakta/data, kemudian menghubungkan data/fakta yang satu dengan fakta/data lainnya, menganalisis data-data/fakta-faktatersebut yang diperoleh baik hasil pengamatan maupun hasil wawancara dengan beberapa anggota DPRD Kota Sorong maka penulis dapat menarik kesimpulan sebagai berikut : (1) Bahwa dengan otonomi daerah sejak tahun 1999 sampai sekarang telah mampu membawa perubahan dan memberikan dampak positif bagi kesejahteraan rakyat dan semakin memberdayaan DPRD termasuk DPRD Kota Sorongdalam rangka melaksanakan fungsifungsinya terutama fungsi pengawasan terhadap pelaksanaan perda Angaran APBD Kota Sorong periode 2014-2019, dan pengawasan kebijakan pemerintah daerah, pengawasan pelaksanaan keputusan kepala daerahserta pengawasan sumber-sumber penerimaan daerah lainnya agar pembangunan daerah dapat berjalan sesuai ketentuan dalam Perda; (2) Faktor-faktor penghambat pelaksanaan pengawasan terhadap perda tentang APBD Kota Sorong, maupun pengawasan kebijakan pemerintah daerah bahwa dalam menjalankan pungsinya mengalami beberapa faktor pemghambat/kendala antara lain ; (a) Masih ada anggota DPRD Kota Sorong yang kurang memahami batasan-batasan dan ruang lingkup tugas pokok dan fungsi pengawasan; (b) Adanya 
perbedaan persepsi diantara anggota DPRD terhadap tugas dan wewenang sehingga pelaksanaan fungsi pengawasan kurang optimal; (c) Masih ada anggota DPRD yang berpendidikan SLTA; (d) Masih ada anggota DPRD yang belum berpengalaman; (e) Sumber daya manusia yang masih terbatas untuk menunjang pelaksanaan fungsi-fungsi DPRD termasuk fungsi pengawasan; (f) Tidak tersedianya fasilitas jaringan pengawasan yang memadai; (f) Peraturan perundangundangan cenderung berubah-ubah, penegakan hukumdan keadilan yang masih lemah;

\section{DAFTAR PUSTAKA}

A H. Birch, dalam Sirajuddin dkk, Legislative Drafting, YAPPIKA, Malang Corruption Watch, 2006, Cet, I,58

Djodjosoekarto Agung dkk, Membangun Kapasitas Penganggaran DPRD, Sekretariat Nasional ADEKSI, (Jakarta : November 2004), hal 1

Hadari Nawawi, Metode Penelitian Bidang Sosial, Gajah Mada University Prers, Yogyakarta, 1991.

Hungtington P.Samuel, Gelombang Demokrasi ke Tiga, Pustaka Grafitti, Jakarta, 1991.

John Naisbitt, Global Paradox, William Company Inc, 1994.

Kaelan H dkk, Pendidikan Kewarganegaraan Perguruan Tinggi, Paradigma,Yogyakarta, 2007, Edisi 1 hal-64.

Kusnardi Moh dkk, Ilmu Negara, Gaya Media Pratama, Jakarta, 2007, Cetakan ke-6.

Manan Bagir, Teori dan Politik Konstitusi, Cet, Kedua, (FK UI Press : Yogyakarta 2004), 142

Mardiasmo, Otonomi Manajemen Keuangan Daerah, Andi, Yogyakarta,2002, hal ,219.

Mardalis, Metode Penelitian Suatu Pendekatan Proposal, Bina Aksara, Jakarta, 2007.

Meriam, Wesbter Online Dictionary 1991

Ridwan, Hukum Administrasi Di Daerah, FH UII Pers, Yogyakarta, 2009,Cet.Pertama, hal,51. Majelis Permusyawaratan Rakyat Republik Indonesia, Panduan Pemasyarakatan UUD tahun 1945 dan TAP MPR RI, Sekretariat Jenderal MPR RI, Jakarta, 2011, edisi ke 10, hal. 86-87.

Samsul Ignatius, Meningkatkan Kinerja Fungsi Legislasi DPRD, (Jakarta: ADEKSI, hal,70.

Sirajuddin dkk, Legislative Drafting, YAPPIKA, Malang, 2006, Cetakan ke 1.

Sarjen T. Lyman, Aspirasi Pemerintahan di Indonesia Studi Sosio Legal Konstitutie,1956-1959 Grafitti, Jakarta, hal- 9.

Sanit Arbi, Perwakilan Politik di Indonesia, Rajawali Press,Jakarta,1990;

Surachmad Winarno,Dasar-dasar dan tehnik Research Survey, LP3S, Jakarta,1991;

Situmorang Juhir, Tujuan Pengawasan (1994:22)

Syaukani, Gaffar Afan dan M. Riyaas Rasyid, Otonomi Daerah dalam Negara Kesatuan, ( Pustaka -Pelajar kerjasama dengan PUSKAP ; Yogyakarta, 2002, hal, $244-245$.

Fungsi Kontrol Masyarakat terhadap Legsilati, eksekutif, dan Yudikatif, (Makalah Forum tatapmuka Tingkat Nasional, Kosgoro: Cipanas, 28 Juli 2002), hal 1-2 Undang-Undang Nomor 22/2003 tentang Susunan dan kedudukan MPR, DPR, DPD dan DPRD. 
Undang-Undang Nomor 12/2003 tentang Pemilihan Umum.

Undang-Undang Nomor 32 tahun 2004, Tentang Pemerintahan Daerah pasal 45 (Kewajiban DPRD),

Fokusmedia,Bandung,2004, Cetakan ke-1.

T Hani Handoko, Manajemen Edisi 2, Yogyakarta, 1984, hal, 359.

Ukas Manan, Tujuan Pengawasan,(2004 : 337 )

Peraturan Pemerintah Nomor 25 tahun 2004 tentang Pedoman Penyusunan Peraturan dan Tata Tertib DPRD.

Peraturann Pemerintah Nomor 24 tahun 2004 tentang Susunan dan kedudukan $M P R, D P R, D P D$ dan DPRD.

Undang-Undang Nomor 27 tahun 2009 tentang Pemerintahan Daerah. 